\title{
ROOST ATTENDANCE AND AGGRESSION IN BLACK VULTURES
}

\author{
PATRICIA PARKer RABENOLD ${ }^{1}$ \\ Department of Biology, University of North Carolina, Chapel Hill, North Carolina 27514 USA
}

\begin{abstract}
In a 5-yr study of a partially marked population of Black Vultures (Coragyps atratus) in North Carolina, turnover among marked birds in a large winter roost averaged $34 \%$ each night. Roost attendance and areawide resighting rates differed among age classes; juveniles remained site faithful while young adults ranged far, and adults were intermediate in movement. Local breeders were more consistent in year-round attendance at roosts near their nest sites than were other marked adults using these roosts, and local breeders were likewise overrepresented on initial days at baited feeding sites. During aggressive interactions at roosts and at food, adults won over young birds and juveniles lost to older birds. Breeding adults won more fights close to their nest sites than farther away. Winners of fights at roosts were more likely to be present on subsequent evenings than were losers. The results suggest that food-finding adults, primarily local breeders, can to some extent control local roost membership by means of aggressive interactions in roosts. Successful foragers can reduce the costs of being followed and sharing food by limiting the number and identity of potential followers through aggression. Received 9 September 1986, accepted 11 April 1987.
\end{abstract}

BLACK Vultures (Coragyps atratus) gather in large roosting groups throughout the year but nest in dispersed, isolated locations. Although roost membership is fluid, relatively stable units of nuclear families and allied families co-occur predictably (Rabenold 1986). High levels of relatedness make active recruitment of followers to food more likely (Waltz 1982) from roosts serving as food-finding information centers (Ward and Zahavi 1973). Evidence that foraging is enhanced for Black Vultures by following from roosts includes: (1) the temporal and directional clumping of roost departures (Rabenold 1983), (2) the return of successful foragers to food visited the day before, (3) the tendency of birds ignorant of the location of food to follow others from roosts, and (4) the larger roosting group sizes and greatly enhanced secondday recruitment to food during the season when food is least abundant (Rabenold 1987). Even with such evidence, it is difficult to embrace the hypothesis that following from the roost is an important mechanism for enhancing foraging. The advantages of roost participation are not obvious for finders of food that are followed from the roost by competitors for food. Sharing selectively with family members and other al-

\footnotetext{
1 Present address: Department of Biological Sciences, Purdue University, West Lafayette, Indiana 47907 USA.
}

lies helps explain the recruitment of followers (Rabenold 1986), but a family group comprises only a small portion of potential followers in this system. Costs of sharing with unrelated followers could be minimized if there existed an effective means of prohibiting following or enforcing reciprocation, and if the cost of these controls were less than the cost of tolerating competitors (Waltz 1983).

I studied aspects of the social organization of Black Vulture roosts that could structure the distribution of benefits from sharing information. I examined patterns of roost attendance, food-finding abilities, and competitive skills in Black Vultures by age class and breeding status. Further, I attempted to determine whether agonistic interactions in a roost influence roost membership. If regular food finders were not only dominant at food but could also limit followers depending on their relatedness, their likelihood of reciprocation, or the local abundance of food, then cooperation in potential information centers is more easily understood.

\section{Materials AND METHOdS}

Study area and population. - The study area was located in Chatham Co. in central North Carolina. Its $250 \mathrm{~km}^{2}$ are $60 \%$ agricultural and $40 \%$ woodland; there are no towns (Reeves et al. 1970). In addition to tobacco, local farms produce mainly poultry, swine, and cattle. Carcasses of these animals are the principal food of the vultures (Rabenold 1987). I studied the 


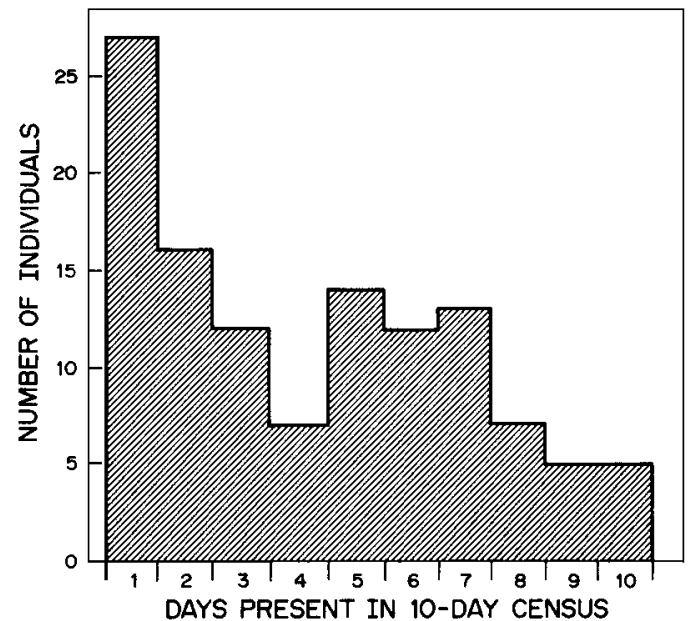

Fig. 1. Days of participation during 10-day winter roost census for 118 marked individuals.

resident population of Black Vultures from autumn 1976 through winter 1982, and began trapping and marking individuals in 1977. Birds were captured primarily in walk-in funnel traps baited with carrion. Each captured bird was classified as adult, young adult, or juvenile based on characteristics of the featherless neck and head (Rabenold 1984). By summer 1981 I had marked 344 Black Vultures with individually numbered vinyl wing tags (Wallace et al. 1980) legible at close range with $10 \times$ binoculars and up to several hundred meters with a $15-60 \times$ zoom telescope.

Approximately 1,200 Black Vultures regularly used the study area year-round (based on a mark-resighting estimate incorporating the proportion of birds marked at roosts and feeding areas and annual mortality of $12.5 \%$ for resident breeders). Not all of these birds roosted there on any given night. Their daily foraging ranges are unknown, but each bird is capable of using the entire study area. For example, I saw marked birds move from roosts to feeding sites 1-14 $\mathrm{km}$ away within $30 \mathrm{~min}$, and I once followed a group of 50 Black Vultures as they left one roost in late afternoon and, drifting and circling, moved to another roost $17 \mathrm{~km}$ away in $40 \mathrm{~min}$. Such long flights are probably uncommon. A study of 6 radio-tagged Black Vultures (Coleman 1985) found their mean 2-yr noncircular home range to be 18,000 ha $(3 / 4$ the size of my study area), and $95 \%$ of radio-tracked vulture activity was within $15 \mathrm{~km}$ of the point where they were trapped.

The study area contained 7 roost sites used by the local population. All were in mixed hardwood-conifer forest near creeks. Although no roost was occupied evexy night, sites were traditional in that each was attended regularly when birds were feeding nearby. According to local farmers, the same sites have been occupied regularly for many years.
Censuses of roosting and feeding groups. - Each of the 7 roosts was censused at least once a week between February 1978 and March 1981. I recorded the total number of Black Vultures, identities of tagged birds, and social interactions involving at least one marked bird. Feeding groups were located by following birds out of the roost to their morning feeding sites or by driving a circuit through the study area while watching for groups of vultures circling or descending. At food, I recorded the same information as in roost censuses.

Testing food discovery.-On 30 occasions a carcass was placed in a field near the edge of the woods. I remained hidden near the bait for all daylight hours until it was discovered by vultures and consumed. In 10 trials carcasses were not discovered within $24 \mathrm{~h}$ and were judged to be too decomposed for a fair trial, and interference (e.g. dogs removing baits) required termination of 7 other trials. In the remaining 13 trials vultures discovered and consumed the baits, and I recorded patterns of arrival, identities of marked birds, and ages of birds that were plainly seen.

\section{RESULts}

\section{Movement Among Roosts}

Stability of roost membership.-During the winter of 1980 I obtained accurate censuses of birds on 10 consecutive days at a large winter roost; 118 marked individuals were seen in this time. The turnover rate among marked birds averaged $34 \pm 10 \%$ daily (Table 1 ), although many birds reappeared after an absence. Participation ranged from 1 to 10 visits over the 10 days $(\bar{x}=$ $4.3 \pm 2.8 \mathrm{SD}$, Fig. 1). If marked and unmarked birds participate in roosts identically, the number of individual birds visiting the roost during the 10-day census can be calculated as the total 10 -day count ( 2,383 birds) divided by the average sighting rate of marked individuals over the 10-day period (520 sightings/118 individuals $=4.4$ sightings $/$ individual), or approximately 542 birds.

The stability of winter roost membership (the proportion of birds appearing on more than half of the days) differed among age classes (Table 2). Juvenile Black Vultures were site faithful, while young adults seldom stayed long at a single roost; adults were intermediate in roost fidelity. Areawide individual resighting rates confirmed the age differences found in roost participation. For each individual sighted at least once after marking, I determined the mean number of resightings per month in the study area from the date of marking through last 
TABle 1. Census of a winter roost.

\begin{tabular}{|c|c|c|c|c|}
\hline Day & $\begin{array}{c}\text { No. } \\
\text { present }\end{array}$ & $\begin{array}{c}\text { No. } \\
\text { marked }\end{array}$ & $\begin{array}{l}\text { Marked } \\
\text { birds } \\
\text { returning } \\
\text { next day }\end{array}$ & $\begin{array}{c}\text { Percentage } \\
\text { of new } \\
\text { marked } \\
\text { birds }\end{array}$ \\
\hline 1 & 200 & 40 & 27 & - \\
\hline 2 & 176 & 41 & 30 & 34.1 \\
\hline 3 & 225 & 56 & 39 & 46.4 \\
\hline 4 & 275 & 57 & 27 & 31.6 \\
\hline 5 & 178 & 37 & 29 & 27.0 \\
\hline 6 & 186 & 50 & 43 & 42.0 \\
\hline 7 & 250 & 55 & 31 & 21.8 \\
\hline 8 & 284 & 55 & 40 & 43.6 \\
\hline 9 & 312 & 69 & 50 & 42.0 \\
\hline 10 & 302 & 60 & - & 16.7 \\
\hline $\bar{x}$ & 238.8 & 52.0 & 35.1 & 33.9 \\
\hline SD & 52.7 & 10.0 & 7.7 & 10.5 \\
\hline
\end{tabular}

sighting. This calculation controls for differential mortality among age classes. The resighting rates for all age classes of birds from unknown nest sites differed significantly (Kruskal-Wallis test, $H=29.157, P<0.001)$. Juveniles (mean number of resightings/month $\pm \mathrm{SE}=$ $1.64 \pm 0.16, n=51$ ) were resighted more frequently than adults $(1.09 \pm 0.09, n=82)$. Young adults were resighted least frequently $(0.64 \pm$ $0.09, n=26$ ); they moved outside the study area much more often than either juveniles or adults. Resighting rates of juveniles $(1.90 \pm 0.31, n=$ 31) from known, local nest sites did not differ significantly from those of adults from these nests $(1.45 \pm 0.14, n=16)$.

Attendance by breeding adults. - Breeding adults participated in local roosts throughout the year. Even during incubation and brooding, the mate not on duty at its isolated nest site joined a local roosting group (Rabenold 1986). A cluster of 4 roosts was found in the northern half of the study area. Within $5 \mathrm{~km}$ of the center of this area I found 8 nest sites to which the same marked adults returned each year. Sightings of marked breeding adults from these nest sites made up $47 \%$ of the 417 sightings of marked adults at these roosts during all seasons, although the breeders accounted for only $17 \%$ of the 92 marked adults ever sighted there $\left(\chi^{2}\right.$ test, $P<0.0001)$. Although local breeding adults were probably no more abundant than other adults in local roosts on any night, they clearly were the most regular participants.

Food finding by breeding adults. _Local breeders tended to arrive first at food sources in the study
TABLE 2. Winter roost attendance by age class.

\begin{tabular}{cccc}
\hline \hline & \multicolumn{3}{c}{ No. of individuals } \\
\cline { 2 - 4 } $\begin{array}{c}\text { No. of days } \\
\text { in attendance }\end{array}$ & Adults & $\begin{array}{c}\text { Young } \\
\text { adults }\end{array}$ & Juveniles \\
\hline $1-5$ & 30 & 17 & 29 \\
$6-10$ & 13 & 2 & 27 \\
& \multicolumn{3}{c}{$\chi^{2}=9.74, P<0.01$} \\
\hline
\end{tabular}

area. At the 13 baited sites found and consumed by vultures, adults were overrepresented relative to younger birds on initial days compared with subsequent days (Rabenold 1987). At the 7 baited sites that continued to attract birds for one or more subsequent days I made 26 sightings of marked birds, all adults, on initial days. Sightings of local breeders comprised 19 of these 26 sightings (73\%); this is far more than expected because the 16 marked breeders accounted for only $17 \%$ of marked adults seen at local roosts $\left(\chi^{2}\right.$ test, $\left.P<0.001\right)$.

\section{AGGRESSIVE INTERACTIONS}

Aggressive interactions included pecking displacements, beak-toss threats, and protracted fights involving shoulder pushing, wing flapping, and grappling with the feet. Recipients responded to beak-toss threats by withdrawing or escalating into fights in which opponents stood side by side and pushed with their shoulders until one lost its balance and was chased away. Shoulder-push fights sometimes escalated to include opponents biting each other's heads or shoulders and holding firmly while pummeling each other with their wings. Opponents occasionally grappled with their feet while flapping their wings for balance, often locking heads while grappling as well. Wingflap and foot fights were violent, and birds often lost feathers. Threats were rarely ignored (176 of 188 aggressive interactions that involved at least one marked bird resulted in retreat), and winners and losers were easily identified. I classified birds that retreated as losers. After breaking away from a violent fight, losers often were chased by winners in running or flying pursuit, during which the loser was beaten again if it stopped or slowed down too soon; pursuit lasted as long as $7 \mathrm{~min}$.

The main arena for social interactions at roosts was the ground at the foot of the roosting trees 
TABLE 3. Outcome of fights at roosts and at food by age class.

\begin{tabular}{lrcr}
\hline \hline & \multicolumn{3}{c}{ Losers } \\
\cline { 2 - 4 } \multicolumn{1}{c}{ Winners } & Adults & $\begin{array}{c}\text { Young } \\
\text { adults }\end{array}$ & Juveniles \\
\hline At roosts & & & \\
$\quad$ Adults & 79 & 33 & 15 \\
Young adults & 7 & 13 & 2 \\
Juveniles & 0 & 0 & 2 \\
At food & & & \\
$\quad$ Adults & 35 & 11 & 12 \\
$\quad$ Young adults & 0 & 1 & 1 \\
$\quad$ Juveniles & 0 & 0 & 1 \\
\hline
\end{tabular}

or a nearby patch of open ground to which birds moved at sunrise. There they sunned themselves, preened, and walked about for variable periods (from $<1$ to $>3 \mathrm{~h}$, even on clear days) before leaving the roost site for the day. Some fights occurred in the trees, but almost all occurred on the ground beneath the roost (170 of 188 aggressive interactions that involved at least one marked bird). There was therefore usually no identifiable object (such as a particular perch or food item) over which roost mates battled.

Outcome of fights by age class. - When all roost fights involving at least one marked bird were summarized over all roosts, age-related dominance was evident (Table 3). Adults won 33 of $40(83 \%)$ fights against young adults, and juveniles lost all encounters against both adults and young adults. Fights between adults at roosts were much more frequent than expected. Adults accounted for $50 \%$ of winter roost membership, so one-quarter of roost fights should have involved two adults if birds interacted regardless of age. Instead, fights between adults constituted 79 of 151 (52\%) roost fights that involved at least one marked bird ( $\chi^{2}$ test, $P<0.001$ ).

Aggressive interactions at food reflected the age-dependent dominance found in roosting interactions (Table 3). Adults won all fights against younger birds $(n=23)$, and juveniles always lost to older birds $(n=13)$. But unlike those occurring at roosts, fights at food were distributed among age classes as expected by chance given the representation of the three age classes at feeding sites $\left(\chi^{2}\right.$ test, $\left.P>0.40\right)$.

Effect of fights on roost attendance. - During the 10-day winter roost census, 68 fights were recorded that involved at least one marked bird, and 20 involved two marked individuals. In 16 of the 20 cases the winner was present on more subsequent evenings than the loser, in 2 cases the loser stayed longer, and 2 cases were tied (sign test, $P=0.001$ ). Fifteen of the 20 fights involved two adults, and the remaining 5 fights involved adults winning over young adults. The results were the same (winners remained while losers left) when the analysis was restricted to the 15 fights between adults (sign test, $P=0.011$ ).

A total of 43 fights involving marked breeding adults with known nest sites was observed at communal roosts during the course of this study. Local breeders won 27 of 33 fights that occurred within $9 \mathrm{~km}$ of their nest sites and only 4 of 10 fights that occurred between 10 and $18 \mathrm{~km}$ from their nest sites $(G=4.405, P<0.05)$.

\section{DISCUSSION}

Membership of individual Black Vultures at a winter roost was not constant from night to night even when group size changed little. On average, one-third of the individuals at a large winter roost were replaced each night. Young adults showed highest turnover rates, while juveniles had the highest roost fidelity. Areawide resighting rates over the course of the study also showed that juveniles were present most frequently and that young adults apparently left the study area most often; adults were intermediate. Among marked adults, local breeding adults were the most regular members at roosts closest to their nest sites. These trends suggest an ontogenetic shift in strategies for Black Vultures. Juveniles still dependent on their parents for direct feeding and competitive assistance within groups (Rabenold 1986) remain where they can be found and protected by their parents. Young adults that no longer receive overt assistance from their parents, and that probably are not effective food finders, wander from roost to roost. And breeding adults are regular and dominant members of roosts near their nest sites and probably are principal food finders.

Increased feeding efficiency with age, owing either to improved food-finding abilities or to competitive skills, has been demonstrated for blackbirds (Weatherhead and Greenwood 1981), Caspian Terns (Sterna caspia; Dunn 1972), Eurasian Oystercatchers (Haematopus ostralegus; Norton-Griffiths 1968), Little Blue Herons (Egretta caerulea; Recher and Recher 1969), Brown Pelicans (Pelecanus occidentalis; Orians 1969), 
Ring-billed Gulls (Larus delawarensis; Burger and Gochfeld 1979), and Griffon Vultures (Gyps rueppellii; Houston 1976). Young adult Black Vultures range far, perhaps exploiting the foodfinding efforts of many groups in turn. As they age, better food-locating and fighting skills develop. Nesting also favors more localized movements.

Local breeding adults account for nearly half the sightings of marked adults in roosts near their nest sites, although they comprise only one-sixth of the marked adults using these roosts. Adults win more fights locally than farther away. These observations, along with the correlation of success in fights with continued participation at a roost, suggest that breeding adults can to some degree control membership of local roosts.

This capacity for eviction of potential followers from roosts is critical in understanding the possible information-center function of Black Vulture roosts. The costs and benefits to food finders of recruiting potential competitors to food have not been measured, or even reasonably defined, for any communally roosting species. Reciprocal altruism (Trivers 1971) could lead to the evolution of aggregations based on serial role changes (a former follower would return the favor and lead others to food when fortune permitted). This form of exchange, however, could easily be invaded by "cheaters" that, when they found food, roosted alone rather than risk being followed by competitors, or that simply never looked for food and always relied on following others. If such cheating could not be controlled, recruitment of potential competitors to food would be disadvantageous. Some compensating advantage for aggregating, strong enough to overbalance the cost of tolerating followers, would have to exist (Alexander 1974, Hoogland and Sherman 1976). The most obvious compensation would be reduced risk of predation. I saw no evidence of predation on roosting vultures during my study; however, other studies suggest that Black Vultures may occasionally fall prey to both avian and mammalian predators (Coleman and Fraser 1986). Current predation rates are so low that the potential for reducing predation through aggregation is impossible to evaluate.

Sufficient evidence that Black Vultures do follow one another from roosts to food (Rabenold 1983, 1987) exists that this alternative deserves full treatment. Information sharing would be more likely if there existed mechanisms to discourage following, as long as the cost of this deterrence was less than the cost of tolerating competitors (Waltz 1983). Being followed probably entails costs to finders in reduced intake, at least during winter. In this system, food sources frequently lasted more than one day. Carcasses undiscovered by vultures during hot summer months often were decayed past edibility by captive birds within $24 \mathrm{~h}$. Similar carcasses undiscovered by vultures during winter often lasted several days (up to 5) with no visible signs of deterioration. A food finder incurs a cost if followers eat food that otherwise would have been available to the finder on the following day. Individual Black Vultures in captivity can eat as much as $600 \mathrm{~g}$ in one day (N. Smith pers. comm.). Although this represents maximum consumption, free-flying birds undoubtedly need more food than captives, so I used $600 \mathrm{~g}$ as an estimate of possible consumption of hungry followers. The most common food sources in this area were carcasses of swine and multiple carcasses of poultry. Carcasses that contain at least $36 \mathrm{~kg}$ of available food, or 60 meals for vultures, are not uncommon. Under summer weather conditions that promote decay beyond edibility in less than 2 days, the finder of a $36-\mathrm{kg}$ food source that is joined by only 25 birds loses the opportunity to feed there the next day (Fig. 2). Under winter conditions food would still be available the next day (Fig. 2), reducing the cost of being followed at least for the first day. This winter finder, however, would still be able to feed only 2 of 3 potential days at the carcass because of the effects of followers. This may represent a serious loss because food sources are less abundant in winter (Rabenold 1987). In this hypothetical example, finders of food incur costs in intake because consumption by followers decreases the duration of the source; direct competitive costs in skirmishes over food items are incurred as well. Aggressive interactions in winter roosts of Black Vultures influence roost membership and thus selectively reduce the number of potential followers. Of the remainder, many are family members that will cooperate in feeding competition (Rabenold 1986).

Age-related foraging abilities, dominance-related roost membership, age-dependent dominance, and familial bonds combine to suggest that costs to food finders are limited, especially with respect to the mobile, potentially parasitic 


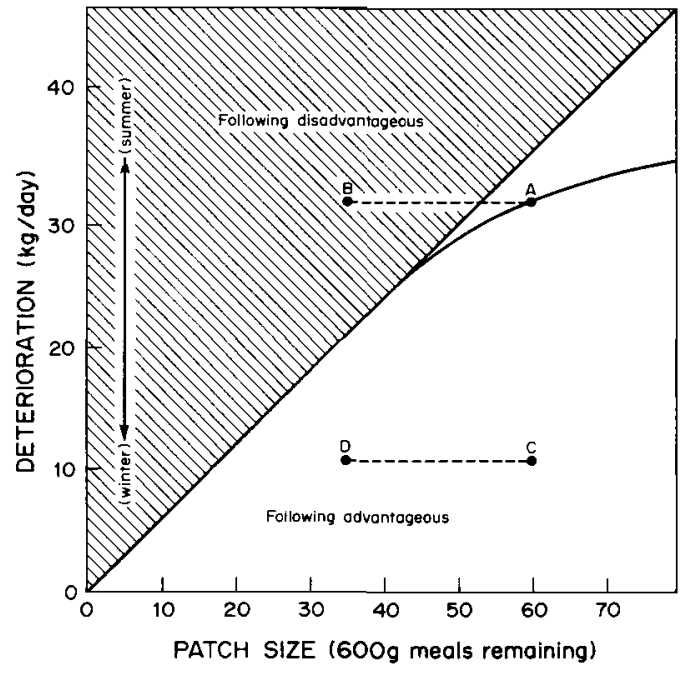

Fig. 2. Hypothetical relationship between amount of food in a patch, deterioration rate, and behavior of birds. The deterioration rate depicted is caused by all factors other than vultures and changes seasonally in this system. "Meals" are measured in 600-g units, the best estimate of maximum daily consumption. At all points on the diagonal, available food matches the deterioration rate; above this line (shaded) following is not advantageous because no food should remain on the following day. Below the line following is advantageous. For naive birds, following from the roost would be a more reliable tactic in winter than in summer. The potential effects of followers are shown by the horizontal dashed lines. A pig carcass weighing $36 \mathrm{~kg}$ represents 60 vulture meals. At summer deterioration rates, 25 followers (the average feeding-group size) would reduce this carcass (A) to the point at which no food would be available on the following day (B). At winter deterioration rates (C), the cost to the finder is less because food will still be available the next day (D). The curve represents the hypothetical shape of the deterioration curve and shows the possibility that large carcasses should decay more slowly per unit mass because of their surface/ volume ratio.

class of young adults. The advantages of participating in roosts probably differ among age classes of Black Vultures if juveniles and young adults are regular beneficiaries of the food-finding efforts of adults. Juveniles wait for their parents, which will feed them directly and defend them in feeding interactions with others (Rabenold 1986). Young adults, however, follow any adults to food and often are not tolerated.

Advantages of roost membership to adults, the principal food finders, must be great to counteract the energetic costs of flying to and from the roost site plus the cost of being followed by competitors. The risk of losing food to unrelated young birds is minimized by adult dominance; the consistent associations of family members further reduce the cost of sharing. Adults probably cannot afford to adopt a strategy of consistently following because of the demands of breeding and of young that are dependent for nearly a year. Breeding restricts adult movement, and they are not as free as nonbreeders to switch roosts. During summer, high decomposition rates of carcasses further curtail the option of exclusive following. The liabilities of roost attendance by informed foragers are limited by direct control of followers and by the potential for inclusive fitness gain by kin alliances. Alliances between nuclear families may represent enduring parent-offspring or sibling bonds (Rabenold 1986). Even if information sharing with unrelated adults occurs, reciprocation in the form of occasional tolerance of followers probably would be enough to favor roost attendance by successful foragers.

\section{ACKNOWLEDGMENTS}

This work was supported in part by a grant from the Frank M. Chapman Fund of the American Museum of Natural History and in part by a UNC Research Fellowship. The cooperation of local landowners, especially the A. J. Perry family and the entire Lindley clan, is greatly appreciated. C. Lewis was an untiring assistant in all phases, and P. Frederick also helped with fieldwork. Earlier versions of this manuscript were improved by comments from J. S. Coleman, J. A. Jackson, J. McNair, W. Richter, R. H. Wiley, and S. Zack. J. Terrell prepared the manuscript. I thank H. C. Mueller for guidance and support, and K. N. Rabenold for his help in many aspects of this study.

\section{LITERATURE CITED}

Alexander, R. D. 1974. The evolution of social behavior. Ann. Rev. Ecol. Syst. 4: 325-383.

BURGER, J., \& M. GOCHFELD. 1979. Age differences in Ring-billed Gull kleptoparasitism on starlings. Auk 96: 806-808.

COLEMAN, J. S. 1985. Home range, habitat use, behavior, and morphology of the Gettysburg vultures. M.S. thesis, Blacksburg, Virginia Polytechnic Inst. and State Univ.

-, \& J. D. FRASER. 1986. Predation on Black and Turkey vultures. Wilson Bull. 98: 600-601. 
DuNN, E. K. 1972. Age and fishing ability of Sandwich Terns. Ibis 114: 360-366.

Hoogland, J. L., \& P. W. Sherman. 1976. Advantages and disadvantages of Bank Swallow (Riparia riparia) coloniality. Ecol. Monogr. 46: 33-58.

Houston, D. C. 1976. Breeding of the White-backed and Ruppell's griffon vultures, Gyps africanus and G. rueppellii. Ibis 118: 14-40.

NORTON-GRIFFITHS, M. 1968. The feeding behaviour of the Oystercatcher Haematopus ostralegus. Ph.D. dissertation, Oxford, Oxford Univ.

OrIANS, G. H. 1969. Age and hunting success in the Brown Pelican (Pelecanus occidentalis). Anim. Behav. 17: 316-319.

RABENOLD, P. P. 1983. The communal roost in eastern cathartid vultures-an information center? Pp. 303-321 in Vulture biology and management (S. R. Wilbur and J. A. Jackson, Eds.). Berkeley, Univ. California Press.

. 1984. The communal roosts of Black Vultures (Coragyps atratus): a test of the information center hypothesis. Ph.D. dissertation, Chapel Hill, Univ. North Carolina.

- 1986. Family associations in communally roosting Black Vultures. Auk 103: 32-41.

- 1987. Recruitment to food in Black Vultures: evidence for following from communal roosts. Anim. Behav. 35: 1775-1785.
RECHER, H. F., \& J. A. RECHER. 1969. Comparative foraging efficiency of adult and immature Little Blue Herons (Florida caerulea). Anim. Behav. 17: 320-322.

Reeves, T. L., M. Blair, J. O. Bearrington, B. HORNY, \& T. TALLEY. 1970. Land development potential study. Prepared for the County of Chatham, North Carolina. HUD Project No. NCP77.

TRIVERS, R. L. 1971. The evolution of reciprocal altruism. Q. Rev. Biol. 46: 35-57.

Wallace, M. P., P. G. Parker, \& S. A. Temple. 1980. An evaluation of patagial markers for cathartid vultures. J. Field Ornithol. 51: 309-314.

WALTZ, E. C. 1982. Resource characteristics and the evolution of information centers. Amer. Natur. 119: 73-90.

- 1983. On tolerating followers in information-centers, with comments on testing the adaptive significance of coloniality. Colonial Waterbirds 6: 31-36.

WARD, P., \& A. ZAHAVI. 1973. The importance of certain assemblages of birds as "informationcentres" for food-finding. Ibis 115: 517-534.

Weatherhead, P. J., \& H. Greenwood. 1981. Age and condition bias of decoy-trapped birds. J. Field Ornithol. 52: 10-15.

We are seeking a person to prepare the next 10-year index to The Auk. The index is a special publication of the American Ornithologists' Union. The next index will cover Volumes 98-107 (1981-1990).

Ideally, the person who prepares the index should have access to a PC. Currently, none of the annual indices are on disk, so the compiler can choose the software system. We are prepared to supply an appropriate package.

If you are interested or know someone who is, please contact the Editor of The Auk. 